\title{
Wildfires in eastern Texas in August and September 2000: Emissions, aircraft
} measurements and impact on ozone formation

\author{
Victoria Junquera ${ }^{\mathrm{a}}$, Yosuke Kimura ${ }^{\mathrm{a}}$, and David Allen ${ }^{\mathrm{a}, *}$ \\ ${ }^{a}$ Center for Energy and Environmental Resources (R7100), The University of Texas at Austin, 10100 Burnet Road, \\ Austin, TX 78758, USA \\ *Corresponding author.Tel.: +1 512-475-7842; Fax.: +1 512-471-7060.E-mail address: allen@che.utexas.edu
}

\begin{abstract}
Summary
The impact of wildfires on ozone concentrations in southeast Texas during August and September of 2000 was assessed through emission inventory development, emission inventory performance evaluation and air quality modeling.

Fire emissions were estimated from acreage burned, fuel loading information and fuel emission factor models. A total of $389 \mathrm{~km}^{2}$ (96,100 acres) burned in wildfires in the domain encompassing the Houston/Galveston-Beaumont/Port Arthur (HGBPA) area during August and September 2000. The amount of acreage burned during these two months in 2000 was approximately an order of magnitude greater than the amount of acreage burned in wildfires during previous years for which detailed emission inventory data are available (1996, 3960 acres; $1997,14,600$ acres). On the days of highest wildfire activity in 2000 , the fires resulted in an estimated 3700 tons of $\mathrm{CO}$ emissions, 250 tons of VOC emissions, 340 tons of $\mathrm{PM}_{2.5}$, and 50 tons of $\mathrm{NO}_{\mathrm{X}}$ emissions; estimated $\mathrm{CO}$ and $\mathrm{VOC}$ emissions from the fires exceeded light duty gasoline vehicle emissions in the Houston area on those days.

When the appropriate aircraft data were available, aloft measurements of $\mathrm{CO}$, mixing heights and wind speeds in the fire plumes were used to estimate emission rates. Emission rates based on emission factors were in excellent agreement with the emission rates based on observations, however, both the emission estimates and the observations had uncertainty bounds of a factor of 2.

The estimated emissions from fires were used, together with a gridded photochemical model (the Comprehensive Air Quality Model with extensions, CAMx), to characterize the extent of dispersion of the fire emissions and the ozone formation associated with the fire emissions during the summer of 2000. Although the dispersion and photochemical impacts varied from fire to fire, ozone concentrations were enhanced by more than $30 \mathrm{ppb}$ at some locations due to fires. For large fires ( $>10,000$ acres), air quality impacts extended over large areas (hundreds of square kilometers).

The effects of fires on ozone concentrations in a future year (2007), with reduced anthropogenic emissions, were also estimated using CAMx. Under conditions with reduced anthropogenic emissions, ozone concentrations were still enhanced by the fire emissions by up to about $30 \mathrm{ppb}$ in some locations. The areas experiencing 1-hour average ozone concentrations above $125 \mathrm{ppb}$ are increased by more than $25 \%$ on some days due to the fires. However, peak area-wide ozone concentrations in the 8-county Houston-Galveston region are only increased by up to about $1 \mathrm{ppb}$ by the fires, using the base case fire inventory developed in this work.
\end{abstract}




\section{Introduction}

Outdoor fires can emit substantial amounts of particular matter (PM), carbon monoxide (CO), non-methane hydrocarbons (NMHCs), nitrogen oxides $\left(\mathrm{NO}_{\mathrm{X}}\right)$, and ammonia $\left(\mathrm{NH}_{3}\right)$ into the atmosphere (Sandberg, 1999). In Texas, emissions of CO and fine particulate matter (particulate matter with diameters less than $2.5 \mu \mathrm{m}, \mathrm{PM}_{2.5}$ ) from fires account for 10\% and 1-2\% of total annual statewide emissions, respectively (Dennis et al., 2002). On days and seasons when large fire events occur, these percentages can be much higher, and fires can dominate emissions and impact air quality over substantial areas (Liu, 2004).

The air quality impacts of fires are often estimated based on predicted emissions. Fire emission predictions are based on estimates of area burned, fuel mass burned per area and emissions per mass of fuel combusted. Significant uncertainties can arise in estimating each of these parameters, thus the emission estimates can be uncertain. Dennis et al. (2002) estimated uncertainties of approximately a factor of 2 in area burned and fuel loadings. Additional uncertainties in assessing the air quality impacts of fires are due to uncertainties in emission factors, which depend on the nature of the combustion (smoldering versus flaming) and the plume rise of the fire.

This work evaluates the uncertainties associated with estimating fire emissions by comparing predicted emissions to observations made during a large air quality field program, conducted in southeast Texas during the summer of 2000. The estimated emissions are used to predict the ozone formation impacts of fires during the study period, and during future years with reduced anthropogenic emissions.

\section{Methodology}

\section{Emissions Inventory}

In this study, emissions from wildfires were estimated for the regional domain shown in Figure 1. Wildfire emissions were estimated for the months of August and September 2000; the measurements to which the emission estimates will be compared were collected during the Texas Air Quality Study (TexAQS), which was conducted from August 15 - September 15, 2000. 


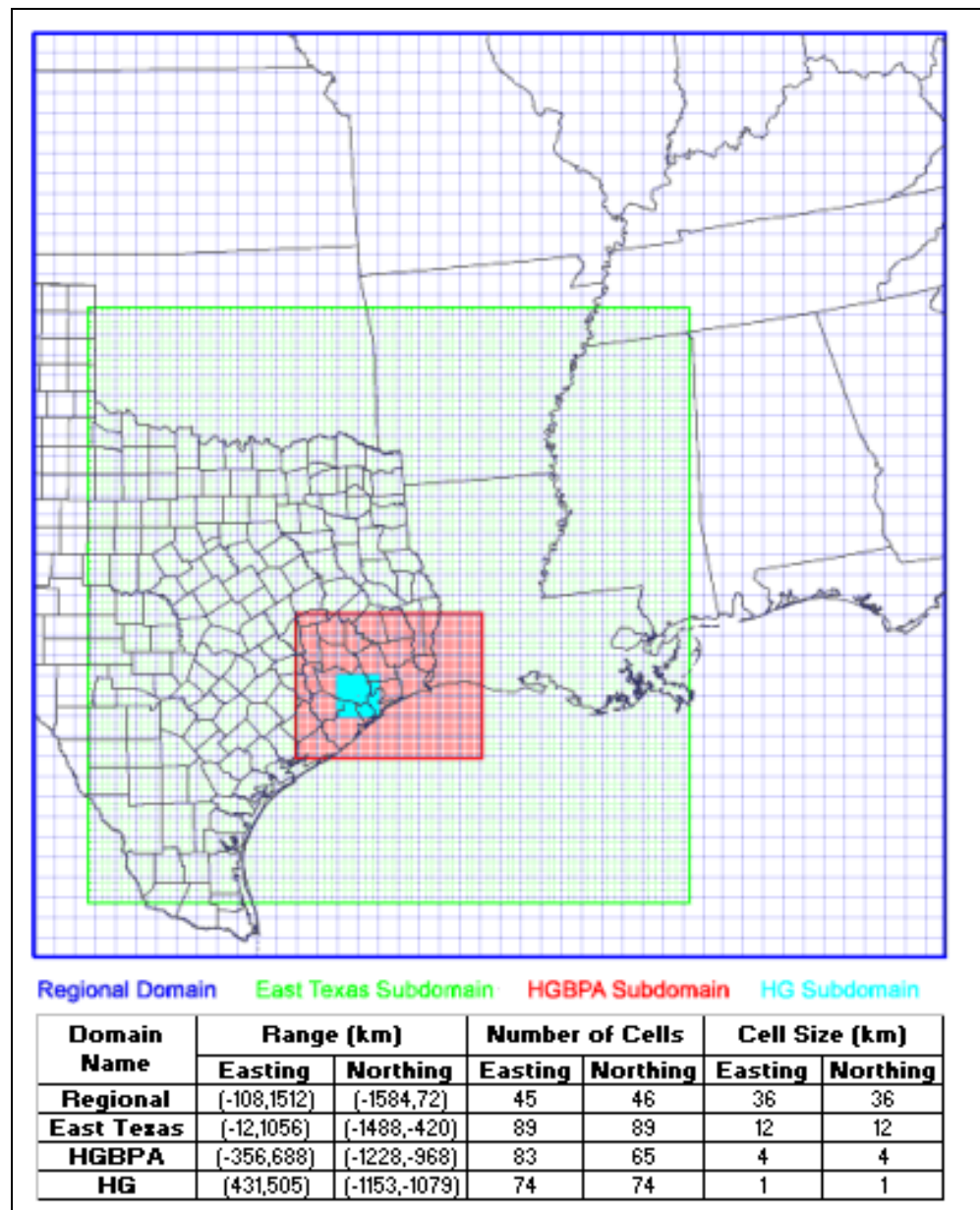

(a)

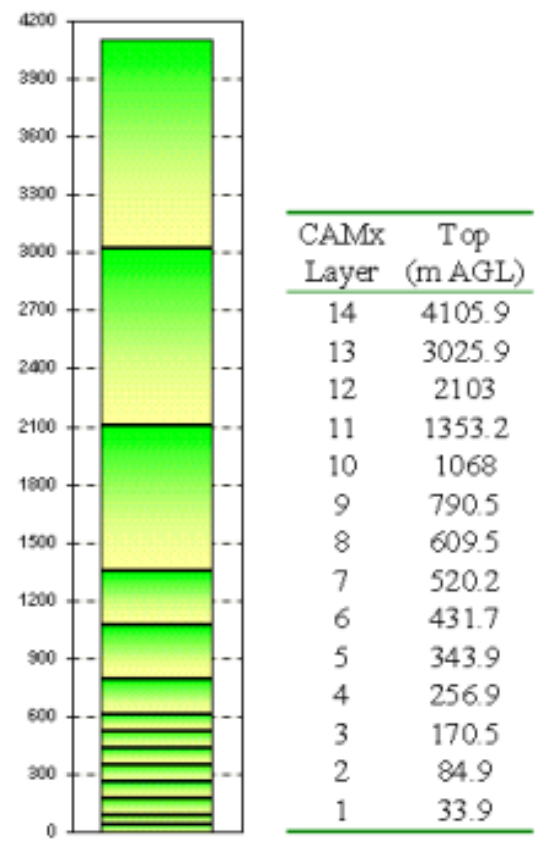

(b)

Figure 1. Horizontal and vertical structure of the domain for the study. Fire emissions during the study period were estimated for the regional domain, with special attention paid to the HoustonGalveston, Beaumont Port Arthur (HGBPA) sub-domain. Emissions were assumed to enter a variety of vertical layers in an air quality model (Comprehensive Air Quality Model with extensions, CAMx).

August and September 2000 was a period of drought and intense wildfire activity in southeast Texas. As documented in the results section, during August and September of 2000 approximately $384 \mathrm{~km}^{2}$ (95,000 acres) burned in wildfires in the HGBPA domain (the red area shown in Figure 1), 66\% of which burned in Texas. In contrast, in August and September of 1996 wildfires consumed $16.0 \mathrm{~km}^{2}$ (3,960 acres), and in August and September of 1997, $59 \mathrm{~km}^{2}$ (14,620 acres) burned in Texas (Dennis, et al., 2002). Because of the intense drought during the summer of 2000, most prescribed burns that would normally occur during August and September 
were delayed or not conducted (Freds, 2002, McCown, 2002; Taylor, 2002), and therefore wildfires dominated the fire emissions during the study period.

The information used to estimate emissions from wildfires includes the location and date of the fire, the fire area, the type of vegetation burned, the density of the vegetation at the location of the fire, also termed the fuel loading factor (mass of fuel available per acre), the fraction of fuel consumed in the fire, the emission factor of the fuel (pounds of pollutant per ton of fuel), and the emission efficiency. The fuel loading factor and the fraction of fuel burned during the fire can be combined into one parameter, the fuel consumption factor (mass of fuel consumed per acre); the fuel consumption factors for specific locations is then combined with fuel based emission factors, into a location specific composite emission factor, in units of emissions of pollutant per acre burned

Wildfire activity data, including acreage burned and fire location, were collected from incident reports available through the National Interagency Fire Management Integrated Database (NIFMID), the Texas Interagency Coordination Center, the U.S. Department of Agriculture Forest Service (USFS), the Louisiana Interagency Coordination Center, and the Oklahoma Department of Agriculture, Food \& Forestry. The information provided by each of these data sources is described in detail elsewhere (Junquera, 2004). All the data concerning individual fire incidents were integrated into a single database and duplicate reports of fires were identified through common parameters, such as the fire incident name and location. Only fires greater than $0.04 \mathrm{~km}^{2}$ (10 acres) were analyzed for duplications in this study, since most of the smaller fires lacked complete information in the databases. It was assumed that duplicated fires under $0.04 \mathrm{~km}^{2}$ would not add significantly to uncertainties in the calculation of emissions.

Once fire locations were determined, fuel consumption was estimated for each fire incident. Vegetation type and density varies significantly over the domain of the study, so the fuel consumption can vary significantly from fire to fire. Relatively little information on vegetation type was available in the incident reports. The type of burned vegetation was reported directly in the fire incident reports for only $9 \%$ of the fires in Texas and $27 \%$ of the fires in the regional domain, or $31 \%$ of the burned area in Texas and $29 \%$ of the burned area in the regional domain. Therefore, in this work, fuel models, rather than reported types of burned vegetation, were used to estimate fuel loading for fires occurring on wildland and rangeland. Specifically, the First Order Fuel Effects Model (FOFEM), a publicly available computer model developed by 
the Intermountain Fire Sciences Laboratory of the USFS, was used to predict fuel consumption (Reinhardt, et al., 1997). The model incorporates vegetation types for the contiguous U.S., and default fuel loading values and consumption equations for each vegetation type (Dennis et al., 2002). The program, however, does not include information on the spatial distribution of these vegetation types. Dennis et al. (2002) selected 15 vegetation cover codes in FOFEM version 4.0, which corresponded to vegetation types in the study domain, and cross-referenced them with vegetation types allocated onto a database of the state of Texas developed by Wiedinmyer et al. (2000). As a result, a land use-land cover (LULC) database with spatially resolved FOFEM 4.0 vegetation cover types and fuel consumption factors was created for Texas. The rest of the study domain was assigned fuel loading factors based on National Fire Danger Rating System (NFDRS) fuel models, which were developed as a method to rate wildfire danger by the USDA Forest Service (Burgan, 1998).

Emissions from wildfires were calculated by projecting the daily fire information (location and acreage) onto a map with spatially resolved composite emission factors. Details of the fuel consumption assignments have been reported by Junquera (2004) and the methods have been described by Dennis, et al. (2002).

\section{Ambient measurements}

A variety of ambient measurements were available to evaluate the performance of the emission estimates. These included total aerosol concentrations (as characterized by aerosol backscatter) as a function of elevation measured by a NOAA aircraft with downward-looking aerosol and ozone Light Detection and Ranging (lidar), and gas phase air pollutant concentrations measured by a second NOAA operated aircraft. Details of the aircraft measurements and operation are described elsewhere (NOAA, 2003; NCAR, 2002) and are only summarized here.

In the lidar measurements, the aerosol channel was set at a wavelength of $359 \mathrm{~nm}$. The aircraft typically flew at an altitude of 3500 meters above middle sea level (MSL), and the aerosol backscatter profiles extend approximately from 2500 meters MSL to the surface with a vertical resolution of 15 meters and a time resolution of 10 seconds (NOAA, 2003). The aerosol lidar backscatter data are not calibrated and therefore provide information about the aerosol 
distribution in a qualitative rather than quantitative manner (NOAA, 2003). The results are archived at the NOAA web site

The National Center for Atmospheric Research (NCAR) Electra aircraft, operated by NOAA's Aeronomy Laboratory, took 1-second interval measurements of various gaseous compounds on several days of the modeling period. The full suite of measurements is described by Ryerson et al. (2003); data sets for all flights are available via 'ftp' or on magnetic tape upon request (NCAR, 2002). In this work, the primary focus will be on measurements of CO.

Measurements from all of these platforms were available for August 15 to approximately September 15, 2000. Particular focus in this work will be on measurements made on August 30, August 31, and September 3-6. A large fire that occurred on August 30 in Liberty Co., $80 \mathrm{~km}$ (50 miles) northeast of Houston, caused locally elevated PM and ozone concentrations, and its plume could have affected the Houston area on August 31. September 3-6 was characterized by very high regional wildfire activity.

\section{Photochemical Modeling}

The wildfire emissions inventory was merged with an existing inventory of emissions from point, area, and mobile sources obtained from the Texas Commission on Environmental Quality (TCEQ) as part of the Houston/Galveston Air Quality Science Evaluation (TCEQ, 2004). The emissions and meteorological modeling data were input into the Comprehensive Air Quality Model with extensions (CAMx), a 3-dimensional eulerian photochemical grid model (ENVIRON, 2000). The modeling domains have a horizontal resolution of 36-by-36 kilometers (regional domain), 12-by-12 kilometers (East Texas subdomain), 4-by-4 kilometers (HGBPA subdomain), or 1-by-1 kilometers (HG subdomain) (Figure 1). The creation of the model-ready input files are briefly described in this section.

CAMx includes two-way grid nesting, and a subgrid-scale Plume-in-Grid (PiG) module to treat the slow dispersion and the chemistry of large point source plumes. Unless the PiG module is turned on, emissions from each point source are instantly dispersed into an entire grid cell volume, given by the grid cell area and the height of the vertical layer.

Wildfires were treated as point sources or "stacks". Each fire was modeled as a series of stacks with identical location and different heights, so that the emissions calculated for the wildfire would be uniformly distributed throughout the vertical rise of the plume. The PiG 
module was turned off for all fires, causing emissions to be instantly dispersed into each grid volume. Thus, the emissions from each fire were allocated homogeneously into a volume whose area was given by the resolution of the grid and whose height was given by the height of the grid cell into which the emissions were released. Fire emissions were released into the vertical layer that corresponded to the plume rise of the fire. Thus, the emissions from each fire were allocated homogeneously into a volume whose area was given by the resolution of the grid and whose height was given by the vertical cell into which the fire emissions were injected. The area of a cell in the 4-by-4 kilometer and 12-by-12 kilometer grids is equivalent to roughly 4000 acres and 36,000 acres, respectively. Thus, emissions from fires that are smaller than the grid cell area were initially overdiluted in the model.

The fire emissions inventory was preprocessed using the Urban Airshed Model (UAM) Emissions Preprocessor System (EPS) version 2.0. Input into EPS2.0 includes an emissions data file in Aerometric Information Retrieval System (AIRS) Facility Subsystem (AFS) format (AFS file), a chemical split factor file (CHEMSPLIT), and a temporal split file (TMPRL). The CHEMSPLIT file includes information on the chemical speciation of non-methane hydrocarbon (NMHC) emissions into Carbon Bond-IV (CB-IV) species. In the CB-IV chemical mechanism, species with similar chemical properties are lumped into CB-IV groups that undergo the same chemical reactions. In the TMPRL file, the emissions were assumed to be uniform and constant throughout a day for each fire incident. For fire incidents lasting more than one day, emissions were allocated uniformly throughout the burning period. Details of the chemical speciation used in the model are provided by Junquera (2004).

The plume rise for the fires, which is necessary for 3-D photochemical modeling, was estimated based on calculations performed with FIREPLUME. The FIREPLUME model uses Briggs' two-thirds law (Brown et al., 1999), based on buoyancy effects, and employs different calculation strategies for stable, neutral, and unstable atmospheric conditions. For fires smaller than $0.4 \mathrm{~km}^{2}$ (100 acres), a plume rise value corresponding to the top of CAMx layer 3 (170.5 meters) was assigned. For fires between $0.4-3.2 \mathrm{~km}^{2}$ (800 acres), and greater than $3.2 \mathrm{~km}^{2}$, plume rise values corresponding to the top of CAMx layers 4 (256.9 meters) and 6 (431.7 meters), respectively, were assigned. The rationale for these assignments is described by Junquera (2004). 


\section{Results and Discussion}

\section{Emissions Inventory}

In August and September 2000, $518 \mathrm{~km}^{2}$ (128,000 acres) were burned in wildfires in Texas and $389 \mathrm{~km}^{2}$ (95,000 acres) burned in the HGBPA domain (Table 1). In the HGBPA domain, $2 \%$ of the fires were larger than $3.24 \mathrm{~km}^{2}$ (800 acres) and accounted for $56 \%$ of the total area burned, and $74 \%$ of the fires were smaller than $0.405 \mathrm{~km}^{2}$ (100 acres) and burned only 5 percent of the total area. Figure 2 shows wildfire locations and acreage burned from August 22 to September 6. Estimated emissions of $\mathrm{CO}, \mathrm{NMHCs}, \mathrm{PM}_{2.5}$, and $\mathrm{NO}_{\mathrm{X}}$ in the HGBPA domain are shown in Figure 3. Figure 3 also shows the daily average emissions of CO, NMHCs, and $\mathrm{NO}_{\mathrm{X}}$ from light duty gasoline vehicles (LDGV) in the Houston-Galveston area. Figure 3 shows that emissions of $\mathrm{CO}$ and NMHCs from fires exceeded emissions from LDGV on some days. The highest emissions during this period were approximately 3700 short tons/day, 250 short tons/day, 340 short tons/day, and 50 short tons/day for $\mathrm{CO}, \mathrm{NMHC}, \mathrm{PM}_{2.5}$, and $\mathrm{NO}_{\mathrm{X}}$, respectively.

Table 1: Burned area in $\mathrm{km}^{2}$ (acres) for during the study period; September $2-8$ was characterized by the highest wildfire intensity.

Period

August \& September

September $2-8$
Regional Domain

$971(240,000)$

$386(95,300)$
Texas

$518(128,000)$

$251(62,000)$
HGBPA Domain

$389(96,100)$

$262(64,700)$ 


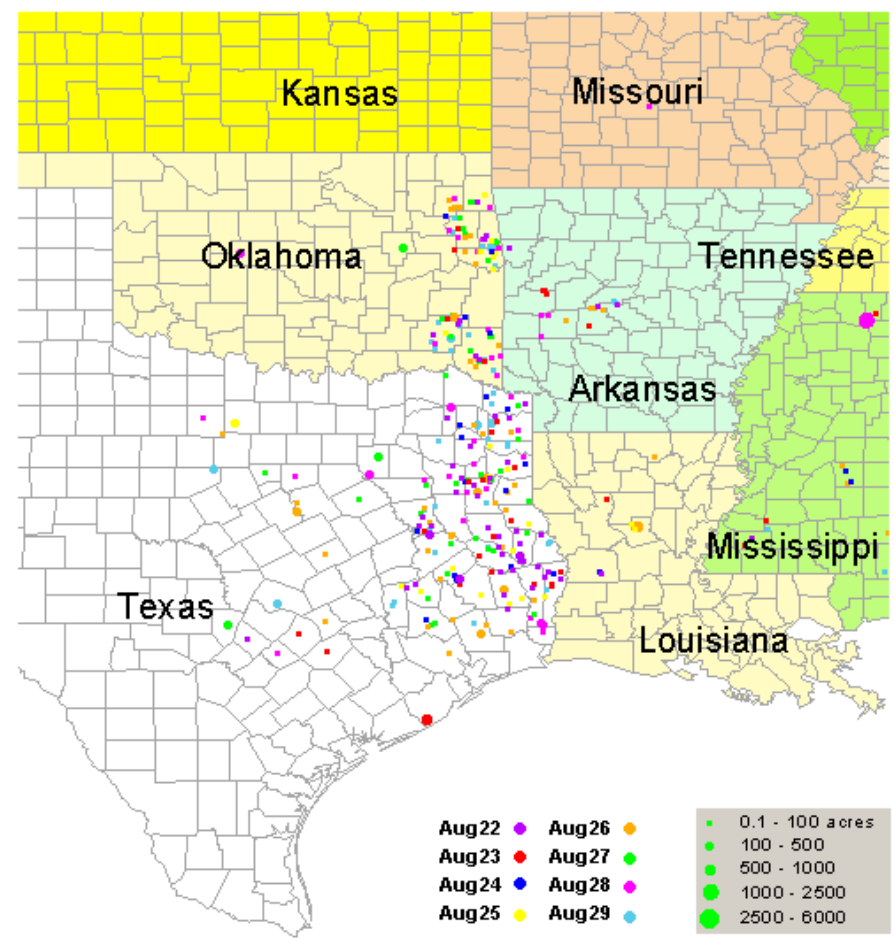

Figure 2a: Wildfires during the period from August 22-August 29, 2000.

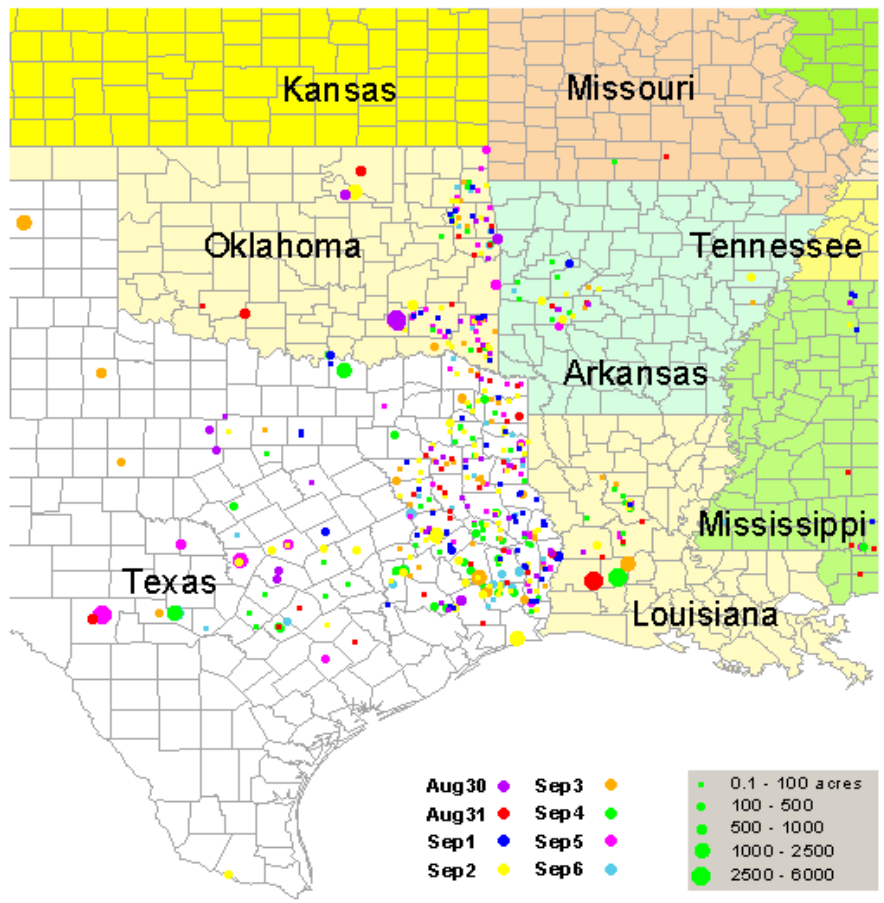

Figure 2b: Wildfires during the period from August 30-September 6, 2000. 


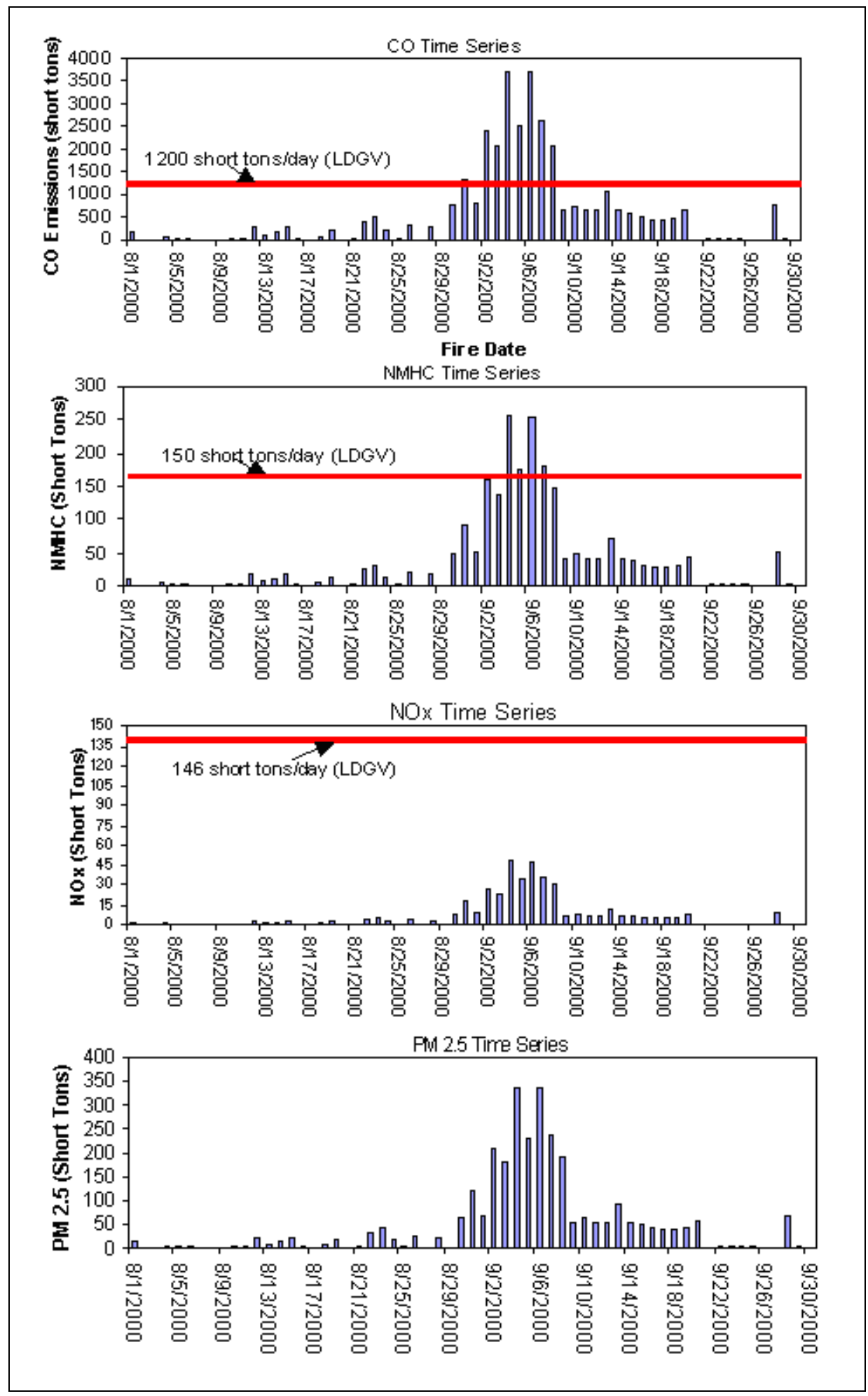

Figure 3: Emissions of $\mathrm{CO}, \mathrm{NMHCs}, \mathrm{NO}_{\mathrm{X}}$, and $\mathrm{PM}_{2.5}$ from wildfires in the HGBPA domain during August and September 2000. Emissions of CO and NMHC from wildfires exceeded emissions from Light Duty Gasoline Vehicles, LDGV (indicated by horizontal line) on some days. 


\section{Comparison with aircraft data}

Aircraft measurements were used to assess the overall accuracy of the emission estimates. The data best suited for this comparison were collected on September 6, in a plume from a multi-day fire in the McFaddin National Wildlife Refuge (NWR) that consumed 13,000 acres. On September 6, the McFaddin NWF fire plume was brought into the Houston area by a northeast wind. Figure 4 shows the location of the fire, the flight track of the NOAA/NCAR Electra aircraft on September 6 and the CO measurements made by the aircraft. Within the fire plume, $\mathrm{CO}$ concentrations of up to $490 \mathrm{ppbv}$ were measured at $\sim 500$ meters above sea level (ASL).

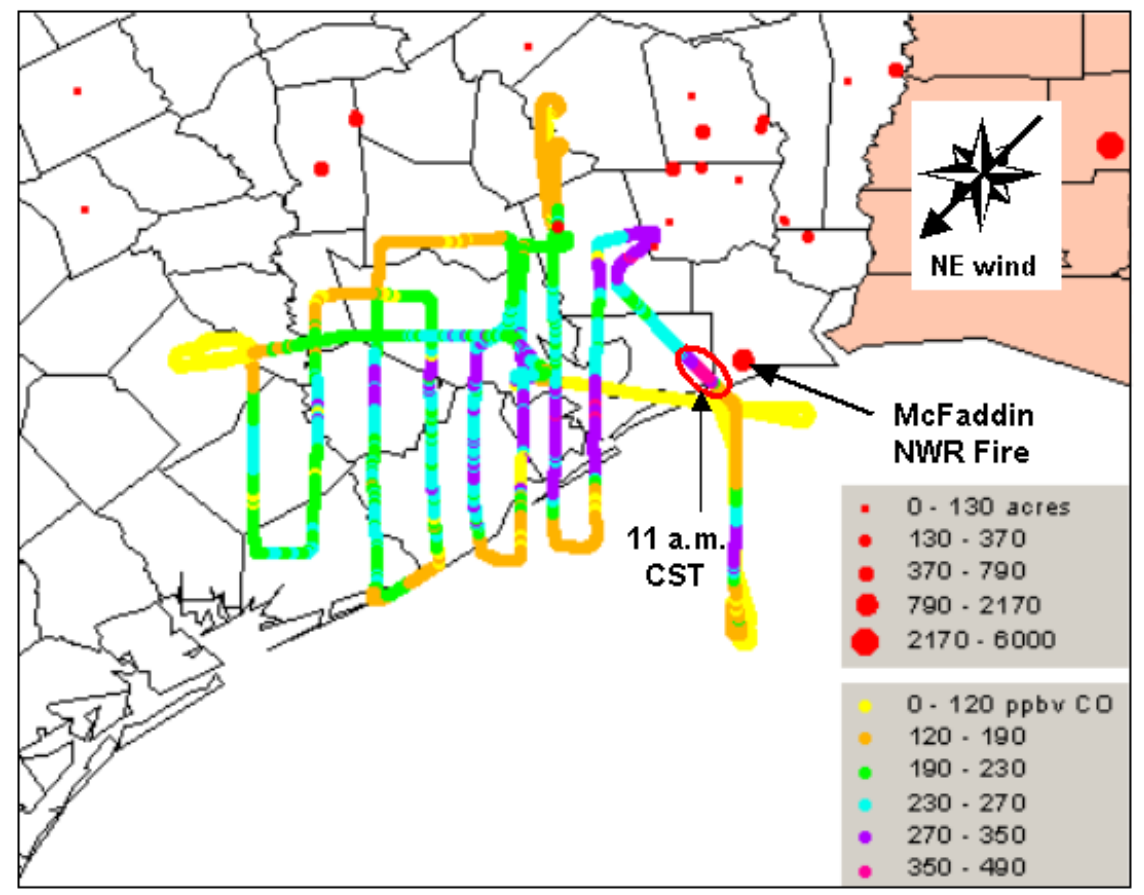

(a)

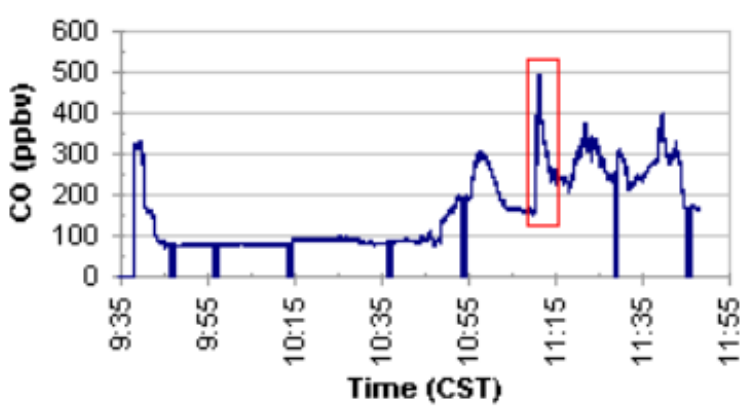

(b)
Figure 4: September 6, CO concentrations measured by NOAA's Electra aircraft. (a) $\mathrm{CO}$ concentrations are represented in different colors, and wildfires sizes are represented by different dot sizes. The CO plume, from the McFaddin National Wildlife Refuge fire, was detected by the aircraft at approximately 11 AM. (b) Detail of the $\mathrm{CO}$ aircraft measurements with the fire plume boxed. 
Background $\mathrm{CO}$ concentrations, or $\mathrm{CO}$ concentration that were not caused by the McFaddin NWR fire, were determined from aircraft measurements before and after the sharp CO peak, and ranged from 80-160 ppbv. The background concentration values were subtracted from the average $\mathrm{CO}$ concentration in the peak caused by the fire, $350 \mathrm{ppbv}$, yielding the concentration caused solely by the fire. Using an average value of the wind speed measured by the aircraft, 5.9 $\mathrm{m} / \mathrm{s}$, the CO flux (mass/area-time) was calculated. It was then assumed that the CO concentration was uniform throughout the mixing height. The mixing height was estimated with HYSPLIT (http://www.arl.noaa.gov/ready/hysplit4.html) for several locations along the flight section that intersected the CO plume, and an average value of approximately 500 meters was obtained. This value was in agreement with mixing height data estimated by Senff et al. (2002) for the Houston area during the early afternoon (400 - 700 meters). Thus, 500 meters was used as the mixing height value. From the mixing height, the length of the cross section of the CO plume due to the fire $(14 \mathrm{~km})$, the average $\mathrm{CO}$ concentration over background in the fire plume and the wind speed, the CO flow (mass/time) was calculated.

The McFaddin NWR was characterized as a marshland in newspaper articles (Houston Chronicle, 2000a,b; Associated Press Newswires, 2000; Baton Rouge Advocate, 2000) and NIFMID reports. The composite emission factor for Wet Grasslands in Texas (FOFEM 6) was therefore chosen to compute the burning rate (acres/time). The burned acreage was then calculated for a 24-hour period.

The fire started September 2 (NIFMID), burned out between two levees on September 4 and 5 (Houston Chronicle, 2000a), was 95\% contained by September 7 (Associated Press Newswires, 2000; Baton Rouge Advocate, 2000), and was completely mopped up by September 9 (NIFMID). From this information, the area that burned on September 6 was expected to fall somewhere between 4 and $20 \mathrm{~km}^{2} /$ day (1,000 and 5,000 acres/day). This estimate of acreage burned per day can be compared to the acreage that would be required to generate the $\mathrm{CO}$ emission rate estimated from the aircraft data (mass/time). The burn rate required to generate the emission rate estimated from the aircraft data was 11-16 $\mathrm{km}^{2} /$ day $(2,800-3,900$ acres/day), depending on the $\mathrm{CO}$ background concentration chosen. Thus, for the McFaddin fire, estimates of emissions and burn rates based on aircraft measurements (11-16 $\mathrm{km}^{2} /$ day burn rates) were 
consistent with the emission inventory data $\left(4-20 \mathrm{~km}^{2} /\right.$ day $)$, but both the inventory and the estimates of emissions based on aircraft measurements have uncertainties of at least a factor of 2.

It should also be noted that the NIFMID inaccurately reported the location of the McFaddin NWR fire, and the location was corrected based on aircraft data and newspaper accounts. In the vegetation map used in this study, the vegetation type existing at the fire location reported by NIFMID (cropland mosaic) was different from the vegetation type at the true fire location (wet grasslands). The fuel loadings, and therefore the emissions associated with the two vegetation types are different. Inaccuracy in fire coordinates may be a source of uncertainty in the emissions inventory, since fuel loadings and emission factors can vary by up to a factor of about 20 depending on the type of vegetation.

\section{Downward-Looking Lidar}

Lidar measurements provide a qualitative measure of the atmospheric concentrations and vertical distribution of PM. Lidar measurements made during the most intense fire period, September 2 to September 8, indicated much higher PM backscatter than during other days of the study. As shown in Figure 5, aircraft measurements on September 3 immediately downwind of the McFaddin NWR fire (red rectangle in Figure 5) indicate that elevated PM concentrations were present throughout the mixed layer. The fire plume was carried into the Gulf of Mexico and was not detected in subsequent measurements on the $3^{\text {rd }}$. On September 6, the Lidar data indicate that elevated PM concentrations were observed at all elevations and throughout the domain. 


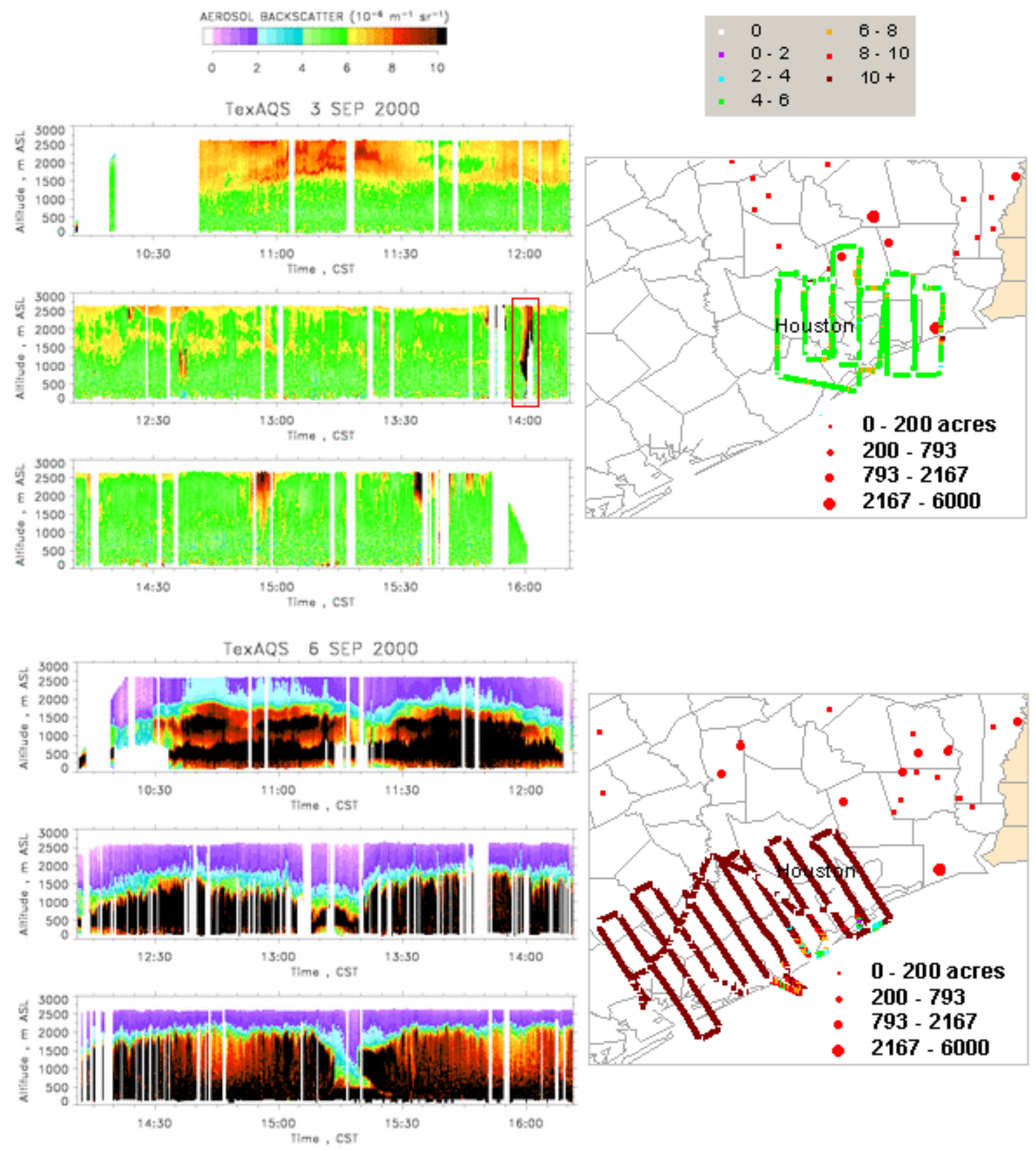

(a)

(b)

Figure 5: (a) PM backscatter registered by the aircraft along its flight path with downwardlooking lidar instrumentation on September 3 (top) and September 6. (b) Corresponding aircraft trajectories and backscatter measured at 2000 meters AGL. September 3 shows a sharp spike in PM backscatter (red rectangle), which was caused by the McFaddin NWR fire. The lidar detected the highest PM backscatter on September 6, the day with the highest fire activity. 


\section{Photochemical Modeling}

More detailed assessments of the air quality impacts of fires can be performed using 3-D gridded photochemical models. In this work, CAMx was used as the modeling tool and the modeling analyses examined the spatial dispersion of fire emissions, the impact of fire emissions on ozone formation and the effect of plume rise assumptions on the impacts of the fires. In the analyses, CAMx simulations were performed both with and without the emissions from fires included. The difference between these simulations characterizes the impact of the fires.

Appendix A shows a series of difference plots (concentrations predicted by the simulation including fire emissions with fire emissions in the vertical layer corresponding to the plume rise height minus concentrations predicted by simulation without fire emissions) for $\mathrm{CO}$ and ozone. The Appendix shows, for each hour of the modeled episode, the difference in $\mathrm{CO}$ and ozone concentrations. Figure 6 shows one of these hours, 2 PM on September 6. CO is shown because, as a slow-reacting species, it characterizes the dispersion of the fire emissions. Ozone is shown since the fire emissions are ozone precursors. Ozone concentrations are enhanced by up to $15 \mathrm{ppb}$ because of fire emissions on September 6. As shown in the Appendix, on some other days (e.g., September 3 and 4), ozone concentrations were enhanced by more than $30 \mathrm{ppb}$. On September 6, some of the greatest ozone enhancements occur over heavily populated regions of Harris County.

\section{Difference in O3 Mixing Ratio}

\section{Difference in CO Mixing Ratio}

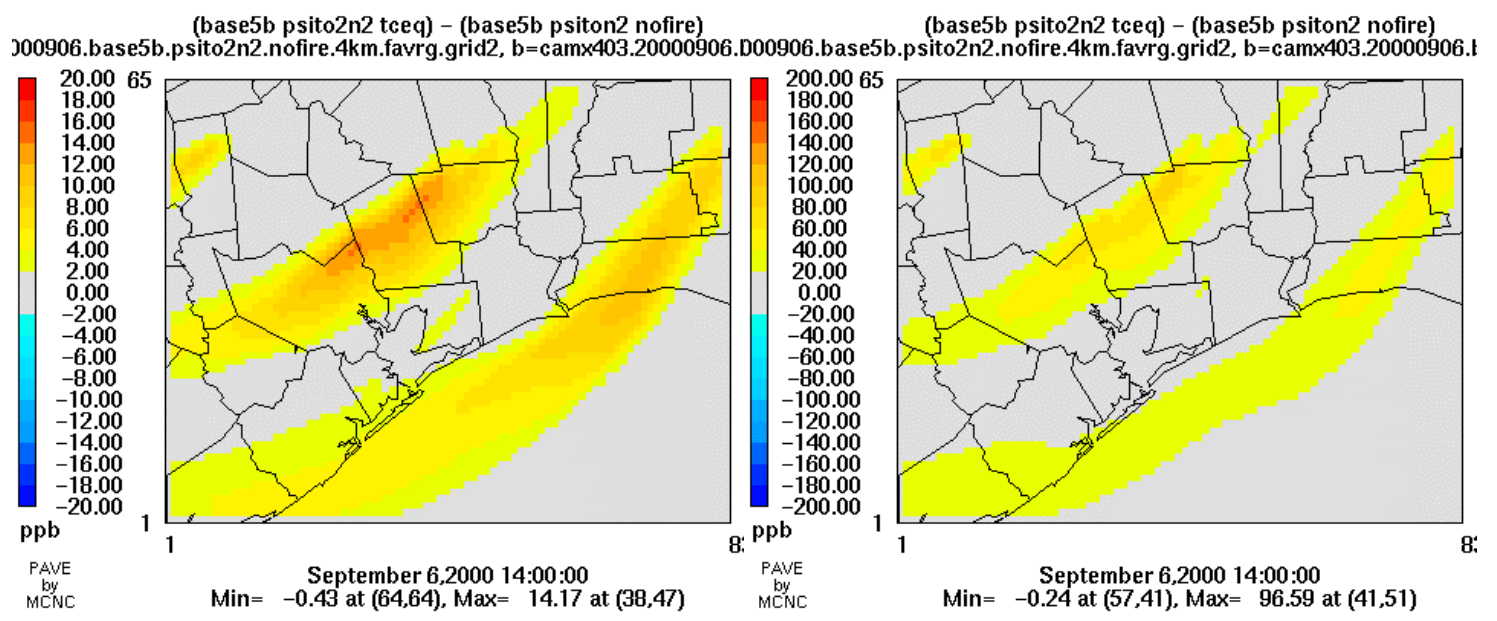

Figure 6: Difference plots (concentrations predicted by the simulation including fire emissions with fire emissions distributed through all vertical layers up to the plume rise height - concentrations predicted by simulation without fire emissions) for $\mathrm{CO}$ and ozone. The figures show, for September 6 at 2PM, the differences in $\mathrm{CO}$ and ozone concentrations due to fires. Similar difference plots, for the entire August 22-September 6 episode, are given in the Appendix. 
These simulations may have been influenced by assumptions made about the vertical distribution of fire emissions. Therefore, the sensitivity of the model-predicted concentrations to the vertical distribution of fire emissions was assessed by performing photochemical modeling runs in which all the emissions were evenly distributed between the top of the plume and the ground, instead of being allocated into the vertical layer corresponding to the fire plume rise (elevated release). Figure 7 shows the impact of the fires on September 6 under the two sets of assumptions.

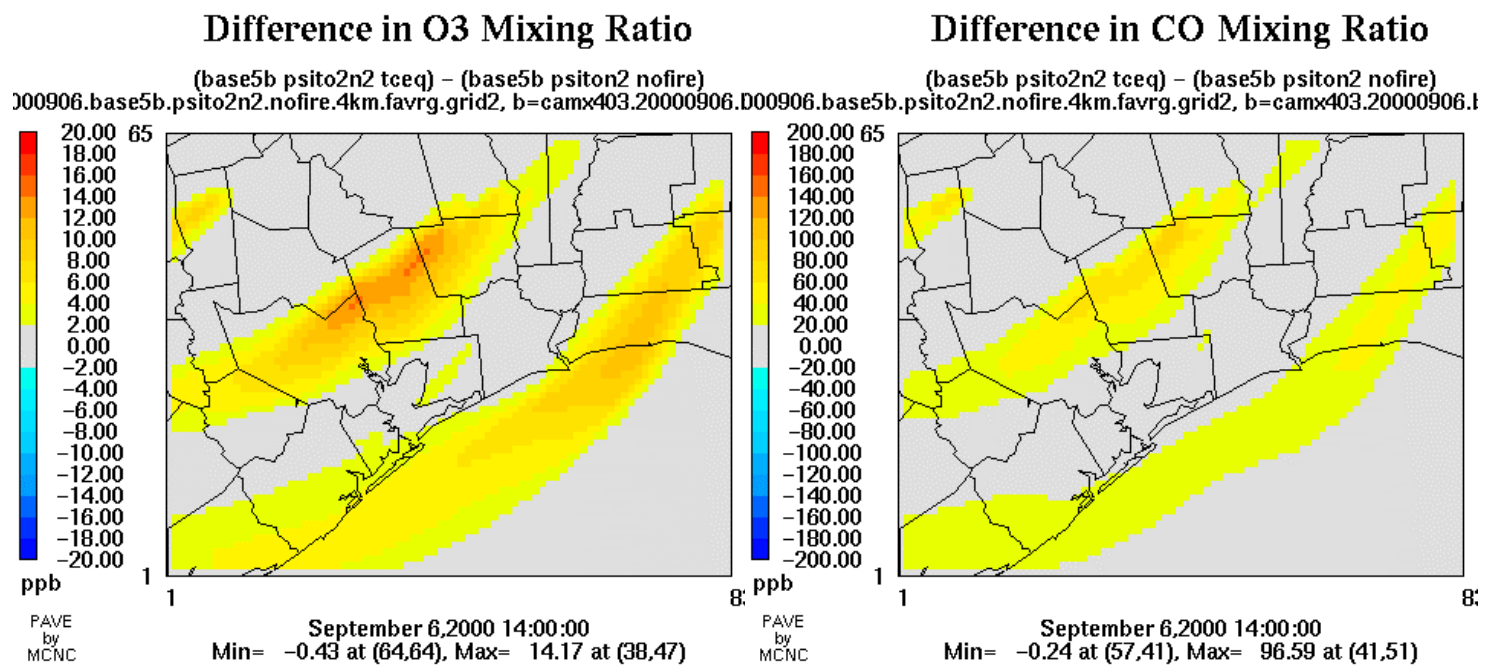

Figure 7a: Difference plots (concentrations predicted by the simulation including fire emissions concentrations predicted by simulation without fire emissions) for CO and ozone (September 6, 2000). Emissions from fires were allocated into the top-most vertical layer of the plume rise.

Difference in O3 Mixing Ratio

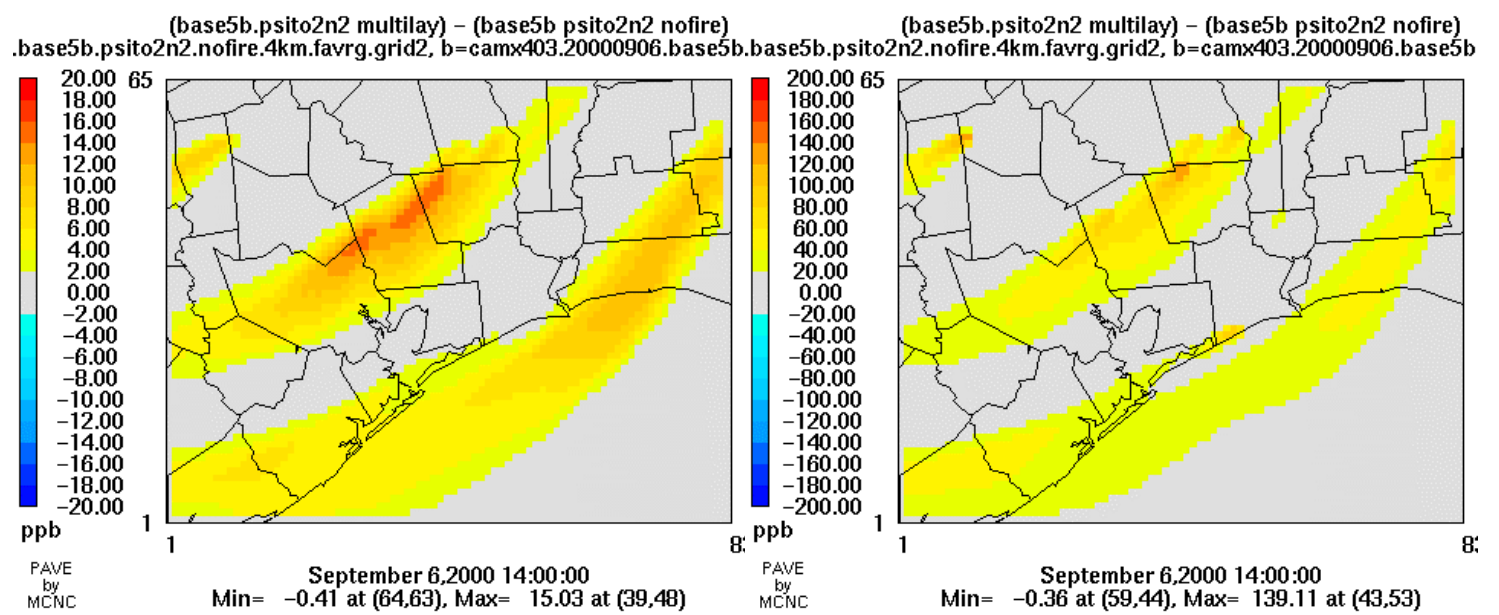

Figure 7b: Difference plots (concentrations predicted by the simulation including fire emissions - concentrations predicted by simulation without fire emissions) for and ozone (September 6, 2000). Emissions from fires were allocated into all layers from the ground to the plume rise height 
The general features of the ozone and $\mathrm{CO}$ enhancement due to the fires are quite similar for the two scenarios shown in Figure 7. The ground level impacts are slightly higher in the case where emissions are distributed uniformly throughout the plume rise, but the difference is relatively small. Similar comparisons for all hours of the episode are available in the Appendix.

\section{Modeled impacts of fire emissions in future years}

As emission reductions from anthropogenic sources take place in the Houston-Galveston area, it might be anticipated that fires could have a smaller impact on regional ozone concentrations, since some ozone formation may be caused by the interaction of wildfire and anthropogenic emissions. To investigate this hypothesis, simulations were performed using a simulated 2007 scenario (this emission scenario represents the proposed control strategy for the Houston-Galveston area prepared by the Texas Commission on Environmental Quality). The future year simulation was performed with and without fire emissions. The difference between these simulations characterizes the impact of the fires.

Appendix C shows a series of difference plots (concentrations predicted by simulation without fire emissions - concentrations predicted by the future case simulation including fire emissions with all emissions occurring at the elevated vertical layer associated with the plume rise) for $\mathrm{CO}$ and ozone. The Appendix shows, for each hour of the modeled episode, the difference in $\mathrm{CO}$ and ozone concentrations. Figure 8 shows data for $2 \mathrm{PM}$ on September 6 (the same time and date as shown in Figures 6 and 7).

Ozone concentrations are still enhanced by the fire emissions by up to about $15 \mathrm{ppb}$ on September 6 (approximately the same results as shown in Figure 6). As shown in the Appendix, on the days that showed some of the largest ozone impacts from fires (e.g., September 3 and 4), ozone enhancements in the future year scenario can still reach more than $30 \mathrm{ppb}$. 


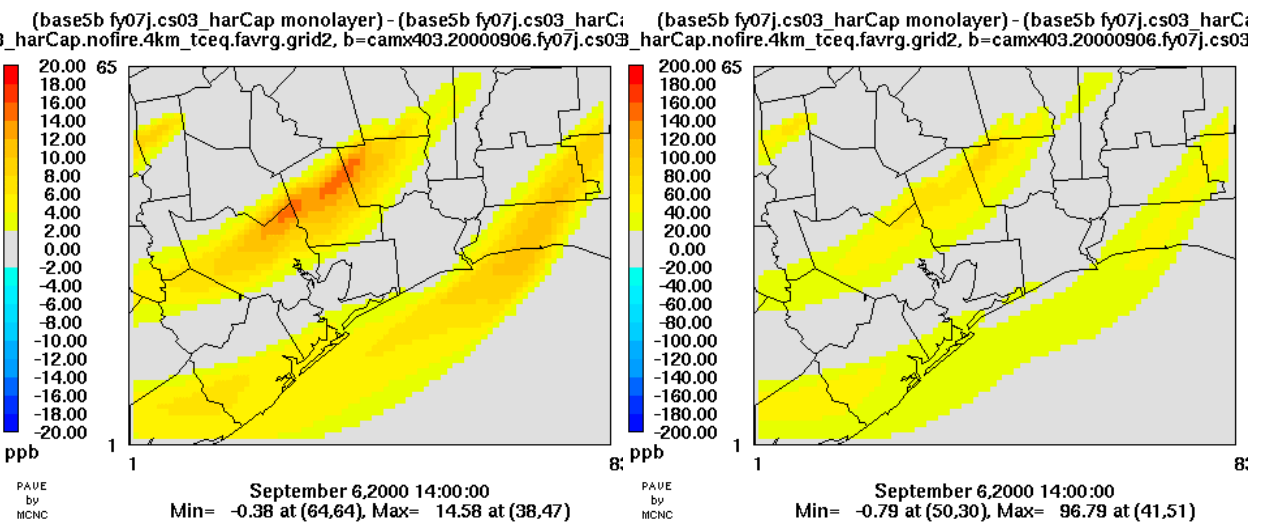

Figure 8: Difference plots (concentrations predicted by the simulation including elevated fire emissions - concentrations predicted by simulation without fire emissions) for $\mathrm{CO}$ and ozone for a future year episode with anthropogenic emission controls. The figures show, for September 6 at $2 \mathrm{PM}$, the differences in $\mathrm{CO}$ and ozone concentrations due to fires. Similar difference plots, for the entire August 22-September 6 episode, are given in the Appendix.

The effects of the fires on air quality metrics relevant to demonstrating attainment with the National Ambient Air Quality Standards for ozone are shown in Table 2. Four metrics relevant to ozone are presented, based on the work of Durrenberger et al. (1999). The four metrics, described below, included maximum 1-hour averaged ozone concentration in the eight-county Houston-Galveston area, total geographic area exceeding a threshold 1-hour average ozone concentration of $125 \mathrm{ppbv}$, time-integrated geographic area of exceedance above a threshold 125 ppb 1-hour average ozone concentration, and total daily population exposure:

\section{Maximum 1-hour ozone concentration}

$M_{\max 8}=\max _{g, h}\left\{c_{g, h}\right\}$

where

$c_{g, h}=$ Modeled ozone concentration (in $\mathrm{ppb}$ ) in grid cell $\mathrm{g}$ at hour $\mathrm{h}$.

This metric was calculated by examining all grid cells in the Houston-Galveston area during each episode day and selecting the maximum 1-hour averaged ozone concentration. 
$p p b v$

$M_{\text {totalarea }}=\sum_{g} a_{g} \max \left\{\delta_{g, h}\right\}$

where

$a_{g}=$ area of grid cell $\mathrm{g}\left(\right.$ in $\left.\mathrm{km}^{2}\right)$

$\delta_{g, h}=\left\{\begin{array}{l}0, c_{g, h} \leq 125 \\ 1, c_{g, h}>125\end{array}\right.$

$\delta_{g, h}=\left\{\delta_{g, 1}, \delta_{g, 2}, \delta_{g, 3} \ldots \delta_{g, 24}\right\}$

This metric was calculated by examining each ground level grid cell in the Houston-Galveston area and determining if, at any time of day, the 1-hour averaged ozone concentration exceeded the threshold concentration of $125 \mathrm{ppb}$. If at any time during the day, a grid cell exceeded the threshold concentration, the value of $a_{g} \max \left\{\delta_{g, h}\right\}$ was set equal to the area of the cell, otherwise, $a_{g} \max \left\{\delta_{g, h}\right\}$ had a value of zero. The quantity $a_{g} \max \left\{\delta_{g, h}\right\}$ was then summed over all cells. This metric considered the spatial extent of exceedance, but did not depend on the magnitude of the concentration over the threshold, the length of time of exceedance, or the time of day of the exceedance.

3. Time integrated geographic area of exceedance above a threshold ozone concentration of 80 $p p b v$.

$$
\begin{aligned}
& M_{\text {time area }}=\sum_{h} \sum_{g} a_{g} \delta_{g, h} \\
& \delta_{g, h}=\left\{\begin{array}{l}
0, c_{g, h} \leq 125, \\
1, c_{g, h}>125
\end{array}\right.
\end{aligned}
$$

This metric was calculated by examining 1-hour averaged ozone concentrations in each grid cell in the Houston-Galveston area for each hour of each episode day and determining if the cells exceeded the threshold 1-hour averaged ozone concentration of $125 \mathrm{ppb}$. The areas of all cells exceeding the threshold were then summed for each hour. The areas for each hour were then summed over the day. This metric considered both the temporal extent and spatial extent of the 
exceedance, but did not depend on the extent to which the ozone concentration exceeded the threshold.

\section{Total daily population exposure.}

$M_{\text {pop }}=\sum_{h} \sum_{g} p_{g} \mathrm{~s}_{g, h}$

Where, $s_{g, h}=\left\{\begin{array}{c}0, c_{g, h} \leq 125 \\ c_{g, h}-125, c_{g, h}>125\end{array}\right.$

$p_{g}=$ Population density in each grid cell. The population data were obtained from block level 1990 U.S. Census data, (http://factfinder.census.gov, 2003) that was gridded with ArcGIS software at the same resolution as the model output $(4 \mathrm{~km} \mathrm{x} 4 \mathrm{~km})$. This metric is calculated, for each grid cell, by multiplying the population density by the ozone concentration over the threshold (shown here as $125 \mathrm{ppb}$ ). The sum is taken over the total area of the eight counties, and then summed over hours. $\mathrm{M}_{\text {pop }}$ is an overall measure of total daily ozone exposure over the threshold within the area of interest. It is responsive to temporal and spatial extent of ozone exceedances, as well as exposure level.

Table 2 shows that eliminating the fires from the simulations reduced peak ozone concentrations in the 8-county Houston-Galveston non-attainment area by, at most, approximately 1\% (approximately $1 \mathrm{ppb}$ ). However, metrics related to the area exceeding the standard (125 ppb) were decreased by up to $25 \%$ on some days, when the fires were eliminated.

\section{Conclusions}

Emissions from wildfires can have a significant impact on regional air quality. This work assessed the accuracy of wildfire emission estimation tools and used air quality models to assess the spatial distribution of the air quality impacts of fires in southeast Texas. Comparison of aircraft measurements and emission estimates demonstrated that, within the uncertainty limits of the tools, emission estimates are accurate. The modeling demonstrated that ozone concentrations can be enhanced by 10-30 ppb over wide areas due to extreme fire events. 
Table 2 Impacts of fires on measures of air quality

a. Base Year (2000) Case with no fires; metrics with thresholds calculated with a threshold of $125 \mathrm{ppb}$

\begin{tabular}{|c|c|c|c|c|c|c|c|c|c|c|c|c|c|c|c|c|}
\hline & 812az2007 & 82322007 & $\begin{array}{l}3124212507 \\
\end{array}$ & $8 / 25 / 2007$ & 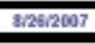 & 812712007 & 828212007 & 812825207 & 83012007 & $851 / 20077$ & 9112507 & 95212007 & 91352007 & S4412007 & $915 / 2007$ & 91622007 \\
\hline 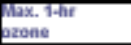 & 107.26 & 80.98 & $\pi .28$ & 158.48 & 189.62 & 11225 & $\begin{array}{l}131.97 \\
\end{array}$ & 151.16 & 137.21 & 17288 & 140.25 & 15283 & 139.16 & 157.08 & 20831 & 151.60 \\
\hline 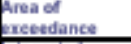 & $0.00 E+00$ & $0.00 E+\infty 0$ & $0.00 E+\infty$ & $1.59 E+03$ & $228 \mathrm{E}+0 \mathrm{a3}$ & $0.00 E=00$ & $5.12 E+02$ & $1.0 \pi \in+03$ & $2.89 E+0.2$ & $288 \mathrm{EE}+03$ & $7.04 E+62$ & $5.50 \mathrm{E}+02$ & $1.28 E+02$ & $1 . \angle 2 E=03$ & $8.22 E+03$ & $1.01 E+03$ \\
\hline 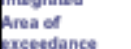 & $0.00 E=00$ & $0.00 E+\infty$ & $0.00 E+\infty$ & $1.79 E+03$ & $307 E+03$ & $0.00 E=00$ & $5.12 E+12$ & $1.44 E+\infty 3$ & $4.98 E+02$ & $6.28 E+03$ & $1.15 E+\infty 8$ & $7.69 \mathrm{EE}+02$ & $240 E+02$ & $2.58 €+03$ & $1.62 E+04$ & $292 E+03$ \\
\hline 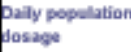 & $0.08 E+00$ & $0.00 E+\infty$ & $0.00 E+\infty$ & $1.80 E+07$ & $1.03 \mathrm{E}+07$ & $0.00 E=00$ & 3.14E+05 & $3 \theta 0 E+\infty 6$ & $3.98 E+05$ & $1.97 \mathrm{E}+07$ & $3.78 E+06$ & 1.1.2E +08 & 1.1.6E +06 & 1.16E 007 & $245 E+08$ & $9.78 E+06$ \\
\hline 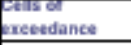 & 0 & 0 & $\circ$ & 90 & 141 & $\circ$ & 32 & 67 & 18 & 179 & 4 & 35 & 8 & 89 & 514 & 63 \\
\hline 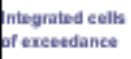 & 0 & 0 & 0 & 112 & 192 & 0 & 32 & 90 & अ1 & 391 & 72 & 48 & 15 & 162 & 1011 & 187 \\
\hline
\end{tabular}

b. Base year (2000) case with elevated fire emissions; metrics with thresholds calculated with a threshold of 125 ppb; note that this inventory, used by the TCEQ in air quality modeling for the Houston area has at least one fire mislocated; but the mislocation has only a small effect

\begin{tabular}{|c|c|c|c|c|c|c|c|c|c|c|c|c|c|c|c|c|}
\hline & 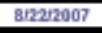 & 82323200 & 812424:2007 & 126512007 & 812642007 & 812721200 & 82820200 & 8I:2812007 & $8=801200$ & 5 & $\$ 11120207$ & Sa212007 & 9152007 & 944:2007 & SI512007 & 91562 \\
\hline 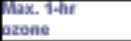 & 107.28 & 80.99 & 77.28 & 158.48 & 109.23 & 11228 & 131.97 & 151.17 & 197.22 & 17301 & 140.38 & 15274 & 139.28 & 157.95 & 209.67 & 152.71 \\
\hline 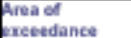 & $0.08 E=00$ & $0.00 E+00$ & $0.00 E+\infty$ & $1.59 E+03$ & $228 \mathrm{E}+03$ & $0.00 E+00$ & $5.12 \mathrm{E}+02$ & 1. $1.07 \mathrm{E}+\infty 3$ & $2.83 E+02$ & $290 \mathrm{E}+03$ & $7.20 E+02$ & $5,50 \mathrm{E}+02$ & 1.28E+02 & $1.5 \mathrm{SE}+03$ & $8.75 E+03$ & $1.08 E+03$ \\
\hline freve of & $0.00 E=00$ & $0.00 E+00$ & $0.00 E+\infty$ & 1.79EE+03 & $307 \mathrm{E}+03$ & $0.00 E+00$ & $5.12 E+02$ & $1.4 E E+\infty 3$ & $4.96 E+02$ & 6.35E+03 & 1.17TE $\bullet 8$ & 7.:GQE+02 & $240 \mathrm{EE}+02$ & $2.85 E+03$ & $1.77 \mathrm{E}+04$ & $3.35 E+09$ \\
\hline $\begin{array}{l}\text { 2aly popelation } \\
\text { lasisge }\end{array}$ & $0.05 E+00$ & $0.00 E+00$ & $0.00 E+\infty$ & $1.80 E+07$ & $1.04 \mathrm{E}+07$ & $0.05 E=00$ & $3.14 E+05$ & $380 E+6 \theta$ & $3.60 E+0.0$ & $1.99 E+07$ & 3.8BE+C6 & 1.14EE+08 & 1.1.77E+66 & $1.98 E+07$ & $201 \mathrm{E}+08$ & $1.05 E+07$ \\
\hline 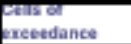 & 0 & a & 0 & 99 & 141 & 0 & 32 & 67 & 18 & 181 & 25 & 35 & 8 & 97 & 547 & 68 \\
\hline 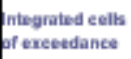 & 0 & 0 & 0 & 112 & 192 & 0 & 32 & $\infty$ & 31 & 397 & 73 & 48 & 15 & 178 & 1108 & 200 \\
\hline
\end{tabular}

c. Base year (2000) case with elevated fire emissions; metrics with thresholds calculated with a threshold of $125 \mathrm{ppb}$; this inventory has the fire with the incorrect location corrected

\begin{tabular}{|c|c|c|c|c|c|c|c|c|c|c|c|c|c|c|c|c|}
\hline & 812122007 & 823232007 & 8124:2007 & 822512007 & 3:2582007 & 812712007 & 82:2820077 & 812820207 & 83012007 & 35112007 & 9112:007 & $92 / 22007$ & 91520077 & 99412007 & 91512007 & $91 / 52507$ \\
\hline $\begin{array}{l}\text { and } \\
\text { azone }\end{array}$ & 107.28 & 80.99 & $\pi .28$ & 158.48 & 129.43 & 11228 & 131.97 & 151.17 & 137.22 & 17302 & 140.31 & 15274 & 139.29 & 157.95 & 209.62 & 152.41 \\
\hline $\begin{array}{l}\text { Areve of } \\
\text { reetdances }\end{array}$ & $0.00 E=00$ & $0.00 E+00$ & $0.00 E+\infty$ & $1.59 E+03$ & $228 \mathrm{EE}+03$ & $0.00 E=00$ & $5.12 E+122$ & $1.0 \pi E+03$ & $2.828 E+02$ & $290 \mathrm{E}+03$ & $7.205 E+62$ & $5.80 \mathrm{~F}+02$ & 1.28EE +02 & $1.55 E+03$ & $8.79 E+03$ & 1. $107 E+\infty 9$ \\
\hline Areace & $0.00 E=00$ & $0.00 E+\infty D$ & $0.00 E+\infty$ & 1.79E+03 & $307 E+03$ & $0.05 E=00$ & 5. $12 \mathrm{E}+022$ & 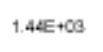 & $4.96 E+02$ & 6.935E+03 & 1.17E $+\infty \mathrm{B}$ & 7.:BgE +02 & $240 E+02$ & $2.85 E+03$ & $1.78 E+04$ & $325 E+\infty 9$ \\
\hline $\begin{array}{l}\text { Daly popelation } \\
\text { dosasgen }\end{array}$ & $0.05 E=00$ & $0.00 E+\infty$ & $0.00 E+\infty$ & $1.80 E+07$ & $1.04 E+07$ & $0.00 E=00$ & 3.14E +05 & $380 E+\infty 6$ & $3.60 E+05$ & $1.99 E+07$ & $3.8 S E \cdot 06$ & 1.14E +08 & 1.17EE +06 & $1.38 E+07$ & $261 \mathrm{E}+08$ & 1. $.05 E+07$ \\
\hline ensuretdanes & 0 & 0 & 0 & $s g$ & 141 & 0 & 32 & 67 & 18 & 181 & 45 & 35 & 8 & 97 & 549 & 67 \\
\hline $\begin{array}{l}\text { Integrathd cells } \\
\text { of exreeddance }\end{array}$ & 0 & 0 & 0 & 112 & 192 & 0 & 32 & 90 & अ & 397 & 73 & 48 & 15 & 178 & 1110 & 200 \\
\hline
\end{tabular}


d. Base year (2000) case with uniformly distributed fire emissions; metrics with thresholds calculated with a threshold of 125 ppb; this inventory has the fire with the incorrect location corrected

\begin{tabular}{|c|c|c|c|c|c|c|c|c|c|c|c|c|c|c|c|c|}
\hline & 8 & E23232007 & 812442807 & 826212007 & 3205622007 & 8127272007 & 821212007 & 8128922007 & 83012007 & $3 / 21 / 20127$ & $9 \mathrm{~V} 112007$ & 95222007 & 915122007 & 944/2007 & 91512007 & 916/52007 \\
\hline 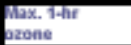 & 10728 & 80.99 & $\pi 7.28$ & 158.48 & 129.43 & 11228 & 131.97 & 151.17 & 137.22 & 17301 & 140.30 & 15274 & 139.25 & 157.75 & 209.50 & 152.44 \\
\hline $\begin{array}{l}\text { rean of } \\
\text { recesdat }\end{array}$ & $0.00 E+00$ & $0.00 E+10$ & $0.00 E+\infty 0$ & 1.58E+03 & $228 \mathrm{EE}+03$ & $0.05 E+00$ & $5.12 E+102$ & $1.07 \mathrm{E}+03$ & $2.89 E+02$ & $290 \mathrm{E}+03$ & $7.20 E+02$ & $5.60 E+02$ & $1.28 \mathrm{E}+02$ & $1.54 \mathrm{E}=03$ & $8.70 E+03$ & $1.07 E+09$ \\
\hline freate & $0.00 E=00$ & $0.00 E+\infty$ & $0.00 E+\infty$ & 1.79EE+03 & $307 \mathrm{EE}+03$ & $0.00 E=00$ & $5.12 E+02$ & $1.4 E E+03$ & $4.96 E+02$ & $6.35 E+03$ & 1.1.7TE $\odot \mathrm{B}$ & 7. $.9 \mathrm{EE}+02$ & $240 E+02$ & $2.8 \mathrm{ZZF}+03$ & 1.79E+04 & $3.25 E+\infty 3$ \\
\hline $\begin{array}{l}\text { Paly popelation } \\
\text { losige }\end{array}$ & $0.0 \mathrm{EE}=00$ & $0.00 E+00$ & $0.00 E+\infty$ & $1.80 \mathrm{E}+07$ & $1.04 E+07$ & $0.05 E=00$ & 3. $14 \mathrm{E}+05$ & $380 E+6 \theta$ & $3.60 E+05$ & $1.99 E+07$ & 3.SEE+C5 & 1.14E+08 & 1.17EE+68 & $1.35 E+07$ & $201 E+08$ & $1.08 E+07$ \\
\hline resseddance & 0 & a & 0 & 90 & 141 & $\circ$ & 32 & 67 & 18 & 181 & 45 & 35 & 8 & 96 & 544 & 67 \\
\hline $\begin{array}{l}\text { Ithegrated eells } \\
\text { fo fexeetdance }\end{array}$ & 0 & 0 & 0 & 112 & 192 & 0 & 32 & 90 & अ & 397 & 73 & 48 & 15 & $17 \theta$ & 1901 & 200 \\
\hline
\end{tabular}

e. Future year (2007) Case with no fires; metrics with thresholds calculated with a threshold of $125 \mathrm{ppb}$

\begin{tabular}{|c|c|c|c|c|c|c|c|c|c|c|c|c|c|c|c|c|}
\hline & & E22325007 & 8 & 825252007 & 825252007 & $8 / 27272007$ & 828212007 & 8128512007 & 83012007 & $3: 1 / 120077$ & 9112807 & 95212007 & $915: 2007$ & 9442207 & 91512007 & 91662207 \\
\hline 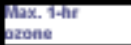 & 88.77 & 7584 & 75.39 & 123.95 & 114.05 & 88.13 & 103.48 & 114.91 & 12399 & 128.29 & 135,48 & 190.81 & 116.11 & 12829 & 187.04 & 126.73 \\
\hline $\begin{array}{l}\text { rea of } \\
\text { rexectada }\end{array}$ & $0.00 E+00$ & $0.00 E+00$ & $0.00 E+\infty$ & $0.00 E+00$ & $0.00 E+\infty 0$ & $0.00 E=00$ & $0.00 \mathrm{E}+00$ & $0.00 E+\infty 0$ & $0.00 E+00$ & $688 \mathrm{EE}+02$ & $8.00 E+01$ & $480 \mathrm{E}+01$ & $0.00 E+\infty 0$ & $3.20 E=01$ & $499 \mathrm{EE}+03$ & $1.78 E+02$ \\
\hline freat & $0.05 E+00$ & $0.00 E+\infty$ & $0.00 E+\infty$ & $0.00 E+00$ & $0.00 \mathrm{E}+\infty$ & $0.00 E=00$ & $0.00 E+00$ & $0.00 E+\infty$ & $0.00 E+00$ & 1.4AE +03 & 1.12E +02 & $6: A 0 \mathrm{E}+01$ & $0.00 E+\infty$ & $3.20 E+01$ & $2.47 \mathrm{E}+03$ & $1.92 \mathrm{E}+02$ \\
\hline 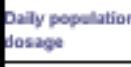 & $0.05 E=00$ & $0.00 E+00$ & $0.00 E+\infty$ & $0,00 E+00$ & $0.00 E+\infty 0$ & $0.00 E=00$ & $0.00 E+00$ & $0.00 E+\infty$ & $0.00 E+00$ & $2.55 E+08$ & 1. $1.85 E+04$ & $184 \mathrm{E}+04$ & $0.00 E+\infty$ & $3.98 E+04$ & 1.:G6E+08 & $4.01 E+04$ \\
\hline Erestance & 0 & a & 0 & 0 & 0 & 0 & a & 0 & 0 & 43 & 5 & 3 & 0 & 2 & \$1 & 11 \\
\hline $\begin{array}{l}\text { Mtegratede eells } \\
\text { of ereetdane }\end{array}$ & 0 & 0 & 0 & 0 & 0 & 0 & 0 & 0 & 0 & 91 & 7 & 4 & 0 & 2 & 502 & 12 \\
\hline
\end{tabular}

f. Future year (2007) case with elevated fire emissions; metrics with thresholds calculated with a threshold of 125 ppb; note that this inventory, used by the TCEQ in air quality modeling for the Houston area has at least one fire mislocated; but the mislocation has only a small effect

\begin{tabular}{|c|c|c|c|c|c|c|c|c|c|c|c|c|c|c|c|c|}
\hline & 8121212007 & 82322007 & 8124212507 & 826512007 & 3:2562007 & 8127212007 & 82282017 & 812821207 & 83012007 & 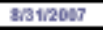 & 94122007 & 520212007 & 91522007 & 944:2007 & $\begin{array}{l}91522007 \\
\end{array}$ & $916 / 2007$ \\
\hline 20zone & 89.77 & 75.85 & 75.39 & 12335 & 114.68 & 88.14 & 103.48 & 11491 & 123.41 & 14858 & 135.42 & 19018 & 116.04 & 127.35 & 187.97 & 127.84 \\
\hline $\begin{array}{l}\text { Areve of } \\
\text { resedtances }\end{array}$ & $0.00 E=00$ & $0.00 E+\infty D$ & $0.00 E+\infty$ & $0.00 E+00$ & $0.00 E+\infty$ & $0.00 E=00$ & $0.00 E+\infty 0$ & $0.00 E+\infty$ & $0.00 E+00$ & $888 \mathrm{E}+02$ & $808 E \cdot 01$ & $4.80 \mathrm{E}+01$ & $0.00 E+\infty 0$ & $6.20 E=01$ & $5.30 \mathrm{E}+03$ & $248 E+02$ \\
\hline 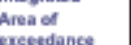 & $0.00 E=00$ & $0.00 E+\infty$ & $0.00 E+\infty$ & $0.00 E+00$ & $0.00 E+\infty$ & $0.0 x E=00$ & $0.00 \mathrm{E}+\infty 0$ & $0.00 E+\infty$ & $0.00 E+00$ & $1.44 E+03$ & 1.12E $+\angle 2$ & GA0E+01 & $0.00 E+\infty$ & 6. $205 E+01$ & $1.03 \mathrm{E}+04$ & $2 B B E+02$ \\
\hline $\begin{array}{l}\text { Daly popelation: } \\
\text { lossage }\end{array}$ & $0.00 E=00$ & $0.00 E+\infty$ & $0.00 E+\infty$ & $0.00 E+00$ & $0.00 E+\infty$ & $0.00 E=00$ & $0.00 \mathrm{E}+\infty$ & $0.00 E+\infty$ & $0.00 E++00$ & $259 E+08$ & 1. $.30 E+04$ & $1.55 E+04$ & $0.00 E+\infty$ & $8.17 E=04$ & $1.79 \mathrm{E}+08$ & $9.75 E+04$ \\
\hline 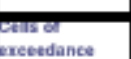 & 0 & a & 0 & 0 & 0 & 0 & a & 0 & 0 & 43 & 5 & 3 & 0 & 4 & 391 & 15 \\
\hline 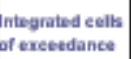 & 0 & 0 & 。 & 0 & 0 & 0 & 0 & 0 & 0 & 91 & 7 & 4 & 0 & 4 & 648 & 18 \\
\hline
\end{tabular}


g. Future year (2007) case with elevated fire emissions; metrics with thresholds calculated with a threshold of 125 ppb; this inventory has the fire with the incorrect location corrected

\begin{tabular}{|c|c|c|c|c|c|c|c|c|c|c|c|c|c|c|c|c|}
\hline & 8 & 823212007 & 8I:24:2807 & 825622007 & 3:252502007 & 8127272007 & 8212120077 & 81:2812507 & $8 / 3012007$ & $8: 312007$ & 9 & 92122007 & 91522007 & S4:12007 & 9:5152007 & 916/2007 \\
\hline 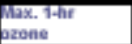 & 89.77 & 75.85 & 75.33 & 12395 & 114.68 & 88.14 & 103.48 & 114.91 & 123.41 & 12858 & 135.53 & 19090 & 1116.21 & 127.40 & 18810 & 128.08 \\
\hline 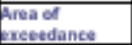 & $0.00 E+00$ & $0.00 E+00$ & $0.00 E+\infty 0$ & $0.00 E+00$ & $0.00 E+\infty 0$ & $0.00 E+00$ & $0.00 E+\infty 0$ & $0.00 E+\infty 0$ & $0.00 E+00$ & $688 \mathrm{BE}+02$ & $800 E+01$ & $8.40 \mathrm{E}+01$ & $0.00 E+\infty 0$ & $\theta . \angle E E+01$ & $5.25 \mathrm{E}+03$ & $2 \pi 2 E+02$ \\
\hline 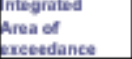 & $0.00 E=00$ & $0.00 E+\infty$ & $0.00 E+\infty$ & $0.00 E+00$ & $0.00 E+\infty$ & $0.05 E=00$ & $0.00 E+\infty 0$ & $0.00 E+\infty$ & $0.00 E+00$ & $1.48 E+03$ & 1. $1.2 E+C 2$ & $8.00 E+01$ & $0.00 E+\infty$ & $\theta .20 E=01$ & $1.03 E+04$ & $3 B 8 E+02$ \\
\hline $\begin{array}{l}\text { Daly popelation } \\
\text { losages }\end{array}$ & $0.05 E+00$ & $0.00 E+\infty 0$ & $0.00 E+\infty 0$ & $0.00 E+00$ & $0.00 E+\infty$ & $0.00 E=00$ & $0.00 E+\infty 0$ & $0.00 E+\infty$ & $0.00 E+00$ & $259 E+08$ & $1.34 E+04$ & $1.50 E+04$ & $0.00 E+\infty$ & $8.41 E=04$ & $1.80 \mathrm{E}+08$ & $1.43 E++\infty 6$ \\
\hline 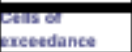 & 0 & a & 0 & 0 & 0 & $\circ$ & 0 & 0 & 0 & 43 & 5 & 4 & 0 & 4 & 328 & 17 \\
\hline 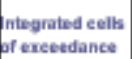 & 0 & 0 & 0 & 0 & 0 & 。 & 0 & 0 & 0 & 91 & 7 & 5 & 0 & 4 & 643 & 23 \\
\hline
\end{tabular}




\section{References}

Associated Press Newswires, 2000. Fires continue to burn throughout Texas, September 7, 2000.

Baton Rouge Advocate, The, 2000. Texas' largest wildfire nearly under control, September 7 , 2000, p. 4-A.

Brown, D., Dunn, W., Lazaro, M., Policastro, A., 1999. The FIREPLUME model: Tool for Eventual Application to Prescribed Burns and Wildland Fires, Proc. from The Joint Fire Science Conference and Workshop, June 15-17, 1999. http://www.nifc.gov/joint_fire_sci/conferenceproc/

Burgan, R., 1988. 1988 Revision to the 1978 National Fire Danger Rating System, Research Paper SE-273. Asheville, NC: USDA Forest Service, Southeastern Region.

Dennis A., Fraser M., Anderson S., and Allen D.T., 2002. Air Pollutant Emissions Associated with Forest, Grassland and Agricultural Burning in Texas, Atmospheric Environment 36, $3779-3792$.

Durrenberger, C., Smith; J., Sullivan, D.; Dean, K., and Zimman, S., 1999. Metrics for demonstrating reasonable further progress, 98-MP24.05, conference paper presented at the Air \& Waste Management Association's $90^{\text {th }}$ Annual Meeting \& Exhibition, Toronto, Ontario.

ENVIRON, 2000. User's Guide Comprehensive Air Quality Model with Extensions (CAMx) version 3.10, ENVIRON International Corporation. Novato, California.

Freds D., 2002. Kerr Wildland Management Area, Hunt, Texas. Personal communication.

Houston Chronicle, The, 2000a. Rice H., Horsewell C., Gonzalez J.W., and Stewart R. Parched conditions keep East Texas wildfires alive, September 6, 2000, p. 1.

Houston Chronicle, The, 2000b. Rice H., Sanders J., Stewart R., and Horsewell C. Smoke from area wildfires may revisit the city today, September 7, 2000, p. 27.

Junquera, V., 2004. Inventory of emissions of gaseous compounds and particulate matter from wildfires in east Texas in August and September 2000 and comparison with aircraft measurements. M.S. Thesis, University of Texas at Austin.

Liu, Y. 2004. Variability of wildland fire emissions across the contiguous United States, Atmospheric Environment 38, 3489 - 3499.

McCown M. (2002). Chambers County Texas Agricultural Extension Agent. Personal communication. 
NCAR, 2002. Project \#2000-828 AESOP/TEXAQS-2000, Texas Air Quality Study, NSF/NCAR L-188 Electra (N308D). National Center for Atmospheric Research, Atmospheric Technology Division, Research Aviation Facility. Web site last updated August 2002. http://raf.atd.ucar.edu/Projects/AESOP

NOAA, 2003. Texas Air Quality Study 2000 Airborne Lidar Aerosol Data, National Oceanic and Atmospheric Administration, Environmental Technology Laboratory, Optical Remote Sensing Division. Web page last modified August 2003. http://www.etl.noaa.gov/et2/data/data_pages/texaqs/air_aerosol.html

Reinhardt, D.E., Keane, R.E., Brown, J.K., 1997. First Order Fire Effects Model: FOFEM 4.0, User's Guide. U.S. Department of Agriculture, Forest Service. Intermountain Research Station, Ogden, Utah.

Ryerson T.B., Trainer M., Angevine W.M., Brock C.A., Dissly R.W., Fehsenfeld F.C., Frost G.J., Goldan P.D., Holloway J.S., Hubler G., Jakoubek R.O., Kuster W.C., Neumann J.A., Nicks Jr. D.K., Parrish D.D., Roberts J.M., Sueper D.T., Atlas E.L., Donnelly S.G., and Flocke F., 2003. Effect of Petrochemical Industrial Emissions of Reactive Alkenes and NOx on tropospheric ozone formation in Houston, Texas, J. Geophys. Res.-Atmos, 108 (D8), 4249 doi:10.1029/2002JD003070.

Sandberg, D.V., Hardy, C.C., Ottmar, R.D., Snell, J.A.K., Acheson, A., Peterson, J.L., Seamon, P., Lahm, P., and Wade, D., 1999. National strategy plan: Modeling and data systems for wildland fire and air quality. U.S. Department of Agriculture, Forest Service, Pacific Northwest Research Station, $60 \mathrm{p}$.

Senff C., Banta R., Darby L., Angevine W., White A., Berkowitz C., and Doran C., 2002. Final Report. Spatial and Temporal Variations in Mixing Height in Houston, TNRCC Project F-20. http://www.etl.noaa.gov/et2/data/data_pages/texaqs/Task_F20_final_report.html

Taylor B. (2002). Texas A\&M University Agricultural Research Station, Sonora, Texas. Personal communication.

TCEQ (2004). Houston/Galveston Air Quality Science Evaluation. Air Quality Modeling Files. CAMx Modeling Files. Files accessed September 2004.

Wiedinmyer C., Strange I., Estes M. Yarwood G., and Allen, D.T. (2000). Biogenic Hydrocarbon Emission Estimates for North Central Texas, Atmospheric Environment 34, $3419-3435$. 